\title{
Current Status of Clinical Evidence for Electromagnetic Hyperthermia on Prospective Trials
}

\author{
TAKAYUKI OHGURI
}

\author{
Department of Radiology, University of Occupational and Environmental Health, 1-1 Iseigaoka, Yahatanishi-ku, \\ Kitakyushu, Fukuoka 807-8555, Japan
}

\begin{abstract}
Japanese Government approved the use of health insurance to cover the costs of electromagnetic hyperthermia in combination with radiotherapy in April 1990. In April 1996, electromagnetic hyperthermia was approved for clinical uses other than combination with radiotherapy. However, the established medical remuneration points of hyperthermia in health insurance were scarce, and tend to prohibit widespread use of electromagnetic hyperthermia due to the decreased profitability.

Level I evidence based on meta-analysis and phase III study for electromagnetic hyperthermia in combination with radiotherapy was recognized in following various disease; head and neck cancer, breast cancer, malignant melanoma, non-small cell lung cancer, cervical cancer, rectal cancer and bladder cancer for local control rate and/or tumor response rate. Level I evidence for electromagnetic hyperthermia in combination with chemotherapy was also seen in patients with high-grade sarcoma and liver cancer.

Improvements of the overall survival rate base on the level I evidence were confirmed in patients with cervical cancer, rectal cancer and high-grade sarcoma. In recent years, promising results for hyperthermia in combination with chemotherapy or chemoradiotherapy based on phase II study were reported.
\end{abstract}

A brief overview of the clinical evidence and future perspective to revise the medical remuneration points for electromagnetic hyperthermia based on prospective trials including ongoing trials is provided in this article.

Key Words : electromagnetic hyperthermia, prospective trial, meta-analysis, phase III study

\section{1.はじめに}

癌に対して行う温熱療法 “ハイパーサーミア”は，1960 年代に培養細胞を用いた温熱の細胞致死効果 が確認されて以降, 本格的な研究が進んだ. 多くの基礎研究がなされ，ハイパーサーミアの癌治療にお ける生物学的な以下のようなメリットが示された ${ }^{1,2)}$. (i) $42-43^{\circ} \mathrm{C}$ 加温により, 加温時間と共に細胞の 生存率が低下する，多くの細胞に共通してみられ，温熱感受性は組織型にあまり左右されない. (ii) 腫 瘍組織のほうが正常組織より加温されやすい. (iii) 低酸素細胞の方が有酸素細胞より温熱に弱い. (iv) 細胞の放射線あるいは抗癌剤からの回復が，温熱により阻止される。（v) 放射線と温熱に対する細胞周

Received 7 March, 2015, Accepted 9 May, 2015. *Corresponding author ; Tel, +81-93-691-7264; Fax, +81-93-692-0249;

e-mail,ogurieye@med.uoeh-u.ac.jp

doi : 10.3191 /thermalmed.31.5

(c) 2015 Japanese Society for Thermal Medicine 
Thermal Med, 31〔2〕: 5-12, 2015.

期の感受性が異なる．このような癌治療における優れた有効性を示す生物学的根拠を基に，電磁波によ る加温装置の開発が進んだ. 1980 年代に数多くの臨床試験が施行され，本邦では 1990 年より放射線治 療併用時にのみ電磁波温熱療法は健康保険適応となった。さらに，1996 年以降は保険適応の拡大によ り全面収載された，以降，改定なく浅在性悪性腫瘍または深在性悪性腫瘍に対する一連の加温につき保 険点数が設定されている．しかしながら，電磁波温熱療法は週に 1 2 回の治療を何度も継続すること で効果が発現されることが多く，経済的・運営面の悪さから本療法が敬遠され普及が阻まれているもの と思われる。

保険適応となった後にエビデンスレベルの高い臨床試験 (メタアナリシスや Phase III study によるレ ベル Iエビデンス）が多数報告されている．また，有望な Phase II studyの結果が出ている疾患群も多 い. 本稿では，今後の診療報酬改定の根拠となりうる電磁波温熱療法の臨床試験の概要や，現在進行中 の電磁波温熱療法の臨床試験も含め概説する。な挆険適応となっていない腹腔内温熱化学灌流療法, 膀胱内温熱化学療法や全身加温法のエビデンスも集積されているが本稿には含まない.

\section{2。温熱放射線療法のエビデンス：浅在性腫瘍}

保険適応以前の 1980 年代から適応後の 1990 年代にかけて，腫瘍内温度上昇の得やすい浅在性腫瘍に 対する温熱放射線療法の臨床試験結果は多く報告されている．頭頸部癌や再発・進行乳癌といった浅在 性腫瘍に対する温熱療法の有効性を検討した Phase III study が多数施行されている．Table I のように，

Table I. Level I evidence for electromagnetic hyperthermia.

\begin{tabular}{|c|c|c|c|c|c|c|c|}
\hline Series $^{\text {ref.) }}$ & Study design & Country & Year & Disease & $\begin{array}{l}\text { Patients } \\
\quad(\mathrm{n})\end{array}$ & Treatment & $\begin{array}{l}\text { Improvement effect by } \\
\text { the addition of HT }\end{array}$ \\
\hline \multicolumn{8}{|c|}{ Thermoradiotherapy for superficial tumor } \\
\hline Vernon $\mathrm{CC}^{3)}$ & Meta-analysis & Five RCTs & 1996 & Recurrent breast cancer & 306 & $\mathrm{RT} \pm \mathrm{HT}$ & TRR \\
\hline $\mathrm{Hua}^{4)}$ & Phase III & China (S) & 2011 & Nasopharyngeal cancer & 180 & $\mathrm{RT} \pm \mathrm{HT}$ & PFS, LC \\
\hline Jones $^{5)}$ & Phase III & USA (S) & 2005 & $\begin{array}{l}\text { Superficial tumor } \\
\text { (recurrent breast cancer etc.) }\end{array}$ & 132 & $\mathrm{RT} \pm \mathrm{HT}$ & $\mathrm{LC}$ \\
\hline Overgaard ${ }^{6)}$ & Phase III & Europe (M) & 1995 & Malignant melanoma & 138 & $\mathrm{RT} \pm \mathrm{HT}$ & $\mathrm{LC}$ \\
\hline Valdagni ${ }^{7)}$ & Phase III & Italy $(\mathrm{S})$ & 1994 & Head and neck cancer & 44 & $\mathrm{RT} \pm \mathrm{HT}$ & OS, LC \\
\hline Perez $^{8,9)}$ & Phase III & $\begin{array}{l}\text { USA (M) } \\
\text { RTOG 81-04 }\end{array}$ & 1991 & $\begin{array}{l}\text { Superficial tumor } \\
\text { (recurrent breast cancer, head } \\
\text { and neck cancer etc.) }\end{array}$ & ad & $\mathrm{RT} \pm \mathrm{HT}$ & $\begin{array}{l}\text { LC, TRR } \\
(\text { Tumor size } \leqq 3 \mathrm{~cm})\end{array}$ \\
\hline Datta $^{10)}$ & Phase III & India $(S)$ & 1990 & Head and neck cancer & 65 & $\mathrm{RT} \pm \mathrm{HT}$ & $\mathrm{LC}$ \\
\hline \multicolumn{8}{|c|}{ Thermoradiotherapy for deep-seated tumor } \\
\hline Lutgens ${ }^{22)}$ & Meta-analysis & Six RCTs & 2010 & Cervical cancer & 267 & $\mathrm{RT} \pm \mathrm{HT}$ & OS, LC \\
\hline De Haas-Kock ${ }^{21)}$ & Meta-analysis & Six RCTs & 2009 & Rectal cancer & 520 & $\mathrm{RT} \pm \mathrm{HT}$ & OS, TRR \\
\hline Mitsumori $^{20)}$ & Phase III & Asia (M) & 2007 & NSCLC & 80 & $\mathrm{RT} \pm \mathrm{HT}$ & $\mathrm{LC}$ \\
\hline Harima $^{24)}$ & Phase III & Japan (S) & 2001 & Cervical cancer & 40 & $\mathrm{RT} \pm \mathrm{HT}$ & LPFS \\
\hline van der Zee ${ }^{19)}$ & Phase III & Europe (M) & 2000 & Cervical cancer & 114 & $\mathrm{RT} \pm \mathrm{HT}$ & OS, TRR \\
\hline & & & & Bladder cancer & 101 & $\mathrm{RT} \pm \mathrm{HT}$ & TRR \\
\hline Berdov $^{23)}$ & Phase III & Russia (S) & 1990 & Rectal cancer & 115 & $\mathrm{RT} \pm \mathrm{HT}$ & OS, TRR \\
\hline \multicolumn{8}{|c|}{ Thermoradiotherapy for superficial and deep-seated tumor } \\
\hline Horsman ${ }^{2)}$ & Meta-analysis & $\begin{array}{l}\text { Twenty-three } \\
\text { RCTs }\end{array}$ & 2007 & Various cancers & 1861 & $\mathrm{RT} \pm \mathrm{HT}$ & $\mathrm{LC}$ \\
\hline \multicolumn{8}{|c|}{ Thermochemotherapy } \\
\hline Issels $^{30)}$ & Phase III & Europe (M) & 2010 & $\begin{array}{l}\text { High-grade soft tissue } \\
\text { sarcoma }\end{array}$ & 341 & $\mathrm{CT} \pm \mathrm{HT}$ & OS, DFS, LPFS \\
\hline Kondo $^{31)}$ & Phase III & Japan (M) & 1995 & Liver cancer & 26 & $\mathrm{CT} \pm \mathrm{HT}$ & TRR \\
\hline \multicolumn{8}{|c|}{ Thermochemoradiotherapy } \\
\hline Kitamura $^{39)}$ & Phase III & Japan $(S)$ & 1995 & Esophageal cancer & 66 & $\mathrm{CRT} \pm \mathrm{HT}$ & T OS, TRR \\
\hline
\end{tabular}

RCT ; randomized controlled trial, RT ; radiotherapy, HT ; hyperthermia, TRR ; tumor response rate, PFS ; progression-free suvival rate, LC ; local control rate, OS; overall survival rate, LPFS; local progression-free survival rate, $\mathrm{S}$; single-institution study, M; multicenter trial, NSCLC ; non-small cell lung cancer, CT ; chemotherapy, CRT ; chemoradiotherapy. 
メタアナリシスまたは多くの Phase III study で浅在性腫瘍に対して放射線治療に温熱療法を加えること での局所制御率や腫瘍縮小率の有意な改善が得られている ${ }^{3-10)}$. しかしながら，1989 年に報告された米 国の Radiation Therapy Oncology group (RTOG) により施行された最も大規模な浅在性腫瘍に対する Phase III study (RTOG81-04) では有意な改善が得られなかった ${ }^{8}$. この臨床試験で用いられたマイクロ 波加温・測温の QA コントロールに不備が指摘されており，加温装置が腫瘍径 $3 \mathrm{~cm}$ までしか加温でき ないのに，腫瘍径が $3 \mathrm{~cm}$ 以上のものが含まれていた点が問題とされている. 1991 年に追加報告された 同トライアルのサブセット解析では， $3 \mathrm{~cm}$ 以内の腫瘍径の症例に限ると，局所制御率および腫瘍縮小 率のいずれにおいても温熱療法の併用により有意な改善が確認されている9

1996 年には進行・再発乳癌の五つの Phase III study のメタアナリシスが報告され, 局所制御率および 腫瘍縮小率の有意な改善が温熱療法を加えることで得られる点が確認されている ${ }^{3)}$. さらに，進行・再 発乳癌の四つの Phase III studyを対象とした加温データのメタアナリシスでは, 加温データ解析を行 い，良好な腫瘍内温度で加温できた症例は，温度上昇が不良であった症例や放射線単独群と比較して有 意に局所制御率の改善が得られたと報告されている ${ }^{11)}$. European Society for Hyperthermic Oncology (ESHO) は，再発・転移性悪性黒色腫に対して多施設共同の Phase III study を施行し，放射線治療に温 熱療法を加えることで局所制御率および腫瘍縮小率が有意に改善する点を 1995 年に報告している6. 同試験での腫瘍内最低温度は $43^{\circ} \mathrm{C} ， 30$ 分とされており，良好な加温が施行できた点が結果に貢献した ものと推測される. 腫瘍内温度上昇が治療効果に大きく関与する点から, デューク大学のグループは, テスト加温で良好な腫瘍内温度上昇の得られた症例のみを登録し無作為化する Phase III study を施行し 2005 年に報告した ${ }^{5)}$. テスト加温後，13 例（11\%) のみが十分な温度上昇が得られず無作為化されな かったものの，温度上昇の得られた 122 例（再発・進行乳癌を中心とした浅在性腫瘍患者）が登録され た。腫瘍縮小率および局所制御率において温熱放射線治療群は放射線治療単独群に比べ有意な改善が確 認されている.

このように浅在性腫痬 (頭頸部癌, 再発乳癌, 悪性黒色腫) は, メタアナリシスおよび多くの Phase III studyで放射線治療に温熱療法を加えることでの局所制御率や腫瘍縮小率の改善が確認されている. 十分な腫瘍内温度上昇が得られる症例は浅在性腫瘍には多く，温度上昇に伴う放射線増感効果を臨床的 に実感できることは多く, 前述のようにメタアナリシスでも腫瘍内温度上昇と局所制御率・腫瘍縮小率 の関連は確認されている.

副作用に関しては，上述の Phase III studyにおいて電磁波温熱療法を加えることで放射線治療の急 性・晚期障害が有意に増加したとする報告はない22. 電磁波温熱療法特有の副作用として約 $10 \%$ の症例 に皮膚-皮下組織の熱傷を生じるが，その大部分は保存的治療で治癒する12).

\section{3．温熱放射線療法のエビデンス：深在性腫瘍}

深在性腫瘍に広く用いられている誘電型加温装置は，体厚より小さな電極では深部が十分に加温され ないため大型（直径 $25 \mathrm{~cm}$ 以上）の電極が必要であり, 標的病変に比較しかなり広範な領域を加温せざ るを得ない ${ }^{13)}$ ．そのため熱感，皮下脂肪過熱や疲労を生じやすくなり，標的温度の十分な時間の上昇に は患者の体力的負担を生じる. よって深部加温では，放射線治療の良好な増感効果の得られる $42.5^{\circ} \mathrm{C}$ 以 上の温度上昇が浅在部加温のように容易には得られにくい．特に肥満患者では加温領域の皮下脂肪過熱 を生じやすく，温度上昇が不良な点が示されている ${ }^{14)}$.

RTOG により 1980 年代に施行された Phase I/II study では骨盤・腹部の深在性進行癌の総 53 例に温 熱放射線療法が施行されたが，予定された温熱療法の完遂率は $32 \%$ と低く，その原因は患者の温熱療 
Thermal Med, 31〔2〕 : 5-12, 2015.

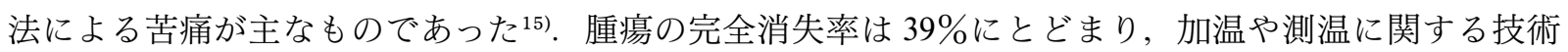
的な問題点が多く指摘された ${ }^{15)}$. 保険適応後の 1990 年代には加温技術の改良がなされた深部加温装置 による温熱放射線治療の Phase I/ II study が複数行われ有望な結果が得られた ${ }^{16-18)}$. その後, 2000 年 にオランダのグループが施行した骨盤内悪性腫瘍に対する放射線治療単独群と温熱放射線療法群を比較 する大規模な Phase III study の結果が報告された，同試験では子宮頸癌においては，全生存率および腫 瘍消失率において温熱放射線治療群で有意な改善が得られた ${ }^{19}$. 膀胱癌においても腫瘍消失率に有意な 改善が確認された ${ }^{19)}$. 2007 年には局所進行肺癌に対する放射線治療単独群と温熱放射線治療群を比較 する Phase III study の結果が報告され, 全生存率の改善は認められなかったものの温熱放射線治療群で 局所制御率の有意な改善を認めている20). 2009 年および 2010 年に直腸癌と子宮頸癌に関する複数の Phase III study に関するメタアナリシスが発表され, 放射線治療に温熱療法を加えることでの全生存率 の有意な改善が確認されている

このように深在性腫瘍の温熱放射線治療は表在性腫瘍と比べ行われた臨床試験は若干少ないが，子宮 頸癌および直腸癌では放射線治療に温熱療法を加えることで全生存率も含めた有効性がレベル I エビデ ンスとして確認されている (Table I) ${ }^{19-24)}$. 非小細胞肺癌や膀胱癌では, 局所制御率や腫瘍縮小率の有 意な改善が Phase III study で確認されている，温熱放射線治療においては浅在性腫瘍と同樣に，深在性 腫瘍でも良好な温度上昇と治療成績との相関が指摘されている ${ }^{25,26)}$. 良好な放射線増感効果が期待され る $42.5^{\circ} \mathrm{C}$ 以上の温度上昇が可能な症例群の選別や，加温技術・装置の精度管理が必要不可欠である. 副 作用は，浅在性腫瘍と同様に，上述の Phase III study で放射線治療の急性・晚期障害が，深部領域の加 温により有意に増加したとする報告はない2).

\section{4. 温熱化学療法のエビデンス}

多くの抗癌剤において温熱による増感効果が得られることが基礎的に確認されている. 白金製剤（シ スプラチン，カルボプラチン，オキサリプラチン)，アルキル化剤 (シクロホスファミド，ニトロソウレ ア) や癌性抗生物質 (ブレオマイシン, マイトマイシン C, アドリアマイシン) は, $40^{\circ} \mathrm{C}$ 前後の比較的低 い温度から増感作用が認められている。代謝拮抗剤 ( $5 \mathrm{FU}$, 塩酸バムシタビン) や植物アルカロイド (イ リノテカン，パクリタキセル，ドセタキセル）においても温熱増感効果が確認されている，抗癌片の細 胞膜の透過性立進や DNA 損傷からの回復阻害が主な機序とされる.

全身化学療法に温熱を加える臨床試験が行われている疾患として高悪性度軟部肉腫がある. 1990-2000 年代に複数の有望な Phase II study の結果が報告された ${ }^{27-29)}$. その後, 温熱化学療法の初の 大規模な Phase III study が ESHO により施行された ${ }^{30}$. 2010 年に結果が報告され, 高悪性度軟部肉腫 の術前および術後化学療法に温熱療法を加えることで, 全生存率, 無病生存率および局所制御率の有意 な改善が得られる点が確認された ${ }^{30)}$. この試験での腫瘍内温度の中央值は $41.8^{\circ} \mathrm{C}$ されており, 温熱放 射線療法ほど高い温度上昇は必要としない印象である。

他の Phase III study として小規模なものではあるが，肝細胞癌または転移性肝癌に対する動注化学療 法に温熱を加える有効性を検討したものがある ${ }^{31}$. 1995 年に報告され, 温熱療法を加えることでの腫 瘍縮小率の有意な改善が確認されている。2000 年以降，再発卵巣癌，癌性腹膜炎，膵癌，非小細胞肺 癌といった難治性の再発・転移癌に対する全身化学療法と温熱療法を加えた温熱化学療法の有望な Phase II study の結果が相次いで報告されている (Table II) ${ }^{32-38)}$. いずれも深部加温法を用いた電磁波温 熱療法である．抗癌剤の増感に必要と推定される温度上昇 (40-41 ${ }^{\circ} \mathrm{C}$ 程度) は大部分の症例で達成しうる 点や浅在性加温ほど手間やテクニックを必要としない点から, 集学的治療に組み入れやすいメリットが 
Table II. Major phase II studies of electromagnetic hyperthermia in recent years.

\begin{tabular}{|c|c|c|c|c|c|}
\hline Series ${ }^{\text {ref.) }}$ & Year & Disease & Patients (n) & Treatment & Outcomes \\
\hline \multicolumn{6}{|c|}{ Thermochemotherapy } \\
\hline Ishikawa ${ }^{32)}$ & 2012 & Pancreatic cancer & 18 & $\mathrm{CT}(\mathrm{GEM})+\mathrm{HT}$ & MST : 17 mos (locally advanced cases) \\
\hline Shen $^{33)}$ & 2011 & NSCLC & 80 & $\mathrm{CT}(\mathrm{CDDP} / \mathrm{GEM}) \pm \mathrm{HT}$ & The addition of HT improved TRR and QOL. \\
\hline Schlemmer ${ }^{34)}$ & 2010 & $\begin{array}{l}\text { High-grade soft } \\
\text { tissue sarcoma }\end{array}$ & 47 & $\mathrm{CT}(\mathrm{EIA})+\mathrm{HT} \rightarrow \mathrm{S}+\mathrm{RT}$ & MST : 105 mos. \\
\hline Fotopoulou ${ }^{35)}$ & 2010 & $\begin{array}{l}\text { Recurrent ovarian } \\
\text { cancer }\end{array}$ & 36 & $\mathrm{CT}($ Doxil $)+\mathrm{HT}$ & MST : 12 mos. \\
\hline $\mathrm{Cho}^{36)}$ & 2008 & $\begin{array}{l}\text { Peritoneal } \\
\text { carcinomatosis }\end{array}$ & 45 & $\mathrm{CT}$ (various) $+\mathrm{HT}$ & 3-y OS : $29 \%$ \\
\hline Jiang $^{37)}$ & 2007 & NSCLC & 29 & $\mathrm{CT}(\mathrm{DOC})+\mathrm{HT}$ & 1-y OS : $45 \%$ \\
\hline \multicolumn{6}{|c|}{ Thermochemoradiotherapy } \\
\hline Hulshof ${ }^{43)}$ & 2009 & $\begin{array}{l}\text { Resectable } \\
\text { esophageal cancer }\end{array}$ & 28 & $\mathrm{CRT}+\mathrm{HT} \rightarrow \mathrm{S}$ & pCR rate: $19 \%, 2-y$ OS : $57 \%$ \\
\hline Westermann ${ }^{40)}$ & 2005 & Cervical cancer & 68 & $\mathrm{CRT}+\mathrm{HT}$ & CR rate : $90 \%, 2-y$ OS : $84 \%$ \\
\hline Jones $^{41}$ & 2003 & Cervical cancer & 13 & $\mathrm{CRT}+\mathrm{HT}$ & CR rate : $100 \%$ \\
\hline $\operatorname{Rau}^{42)}$ & 1998 & Rectal cancer & 37 & $\mathrm{CRT}+\mathrm{HT} \rightarrow \mathrm{S}$ & ORR : $89 \%, 3$-y OS : $86 \%$ \\
\hline \multicolumn{6}{|c|}{ Thermoradiotherapy } \\
\hline Maluta $^{38)}$ & 2007 & $\begin{array}{l}\text { High-risk prostate } \\
\text { cancer }\end{array}$ & 144 & $\mathrm{RT}+\mathrm{HT}$ & 5-y OS : $87 \%, 5$-y bDFS : $49 \%$ \\
\hline
\end{tabular}

CT ; chemotherapy, HT : hyperthermia, GEM ; gemcitabine, CDDP ; cisplatin, EIA ; etoposide, ifosfamide, adriamycin, Doxil ; doxorubicin Hydrochloride, DOC; docetaxel, S; surgery, MST; median survival rate, TRR; tumor response rate, QOL; quality of life, PFS; progression-free suvival rate, LC ; local control rate, OS ; overall survival rate, pCR ; pathological complete response, CR ; complete responce, ORR ; overall resectability rate, RT ; radiotherapy, bDFS ; biochemical disease-free survival rate.

ある. 今後, Phase II study で有望な結果の得られた疾患・レジメの Phase III study の施行が望まれる.

\section{5.温熱化学放射線療法のエビデンス}

1990 年代以降，化学放射線療法の有効性が広く確認され，現在，多くの癌腫において標準的治療と なっているものの，多くの局所進行癌ではさらなる治療成績の改善が望まれている. しかしながら，化 学放射線療法に温熱療法を加える有効性を検討したエビデンスレベルの高い報告は限られている，唯一 結果の報告されている Phase III study として, 食道癌に対して腔内加温法を用いた温熱化学放射線療法 と化学放射線療法との比較がなされており, 温熱を加えることでの全生存率の有意な改善が確認されて いる ${ }^{39)}$. 局所進行子宮頸癌では有望な複数の温熱化学放射線療法の Phase II study の結果があり, 本邦 と ESHO で化学放射線療法に電磁波温熱療法を加える有効性を比較する Phase III study が行われてい るが，まだ結果は報告されていない40,41)。直腸癌においても，局所進行例に対する術前温熱化学放射線 療法の Phase II study の有望な結果があり，現在，ESHOにて Phase III study が施行されている ${ }^{42) . さ ~}$ らに食道癌に扔いても切除可能例に対する術前温熱化学放射線療法の Phase II study の結果を基に, ESHO にて Phase III study が行われている ${ }^{43)}$. その他, 進行乳癌や進行膀胱癌に対する電磁波温熱療法 を用いた温熱化学放射線療法の Phase II study が ESHO にて施行中である.

温熱化学放射線療法は, 食道癌においてレベル I エビデンスを認めるものの, 他の癌腫では Phase II study までの結果である. 今後報告される子宮頸癌, 直腸癌および食道癌の Phase III study の結果が注 目される.

\section{6.まとめ}

1990 年の保険適応後に蓄積された電磁波温熱療法の臨床試験に関して概説した.メタアナリシスま たはPhase III studyに基づくレベル I エビデンスとして，放射線治療に温熱を加えることで頭頸部癌， 
Thermal Med, 31〔2〕: 5-12, 2015.

乳癌, 悪性黒色腫, 非小細胞肺癌, 食道癌, 直腸癌, 子宮頸癌, 膀胱癌と多くの疾患群において局所制 御率や腫瘍完全消失率の有意な改善が確認されている.さらに，子宮頸癌や直腸癌ではメタアナリシス で全生存率においても有意な改善が確認されている，化学放射線療法では，食道癌において温熱療法に よる全生存率の有意な改善が Phase III study で確認されている，化学療法に温熱を加える有効性は，高 悪性度軟部肉腫では全生存率の改善, 肝臟癌では腫瘍縮小率の改善がレベル I エビデンスとして認めら れる.また，有望な温熱化学療法の Phase II study の認められる疾患として，非小細胞肺癌，膵癌，卵 巣癌, 癌性腹膜炎が挙げられた。

\section{参考文献}

1) Dewhirst M.W., Viglianti B.L., Lora-Michiels M., Hanson M., Hoopes P.J. : Basic principles of thermal dosimetry and thermal thresholds for tissue damage from hyperthermia. Int J Hyperthermia, 19: 267-294, 2003.

2) Horsman M.R., Overgaard J.: Hyperthermia : A potent enhancer of radiotherapy. Clin Oncol (R Coll Radiol), 19: 418-426, 2007.

3) Vernon C.C., Hand J.W., Field S.B., Machin D., Whaley J.B., van der Zee J., van Putten W.L., van Rhoon G.C., van Dijk J.D., Gonzalez Gonzalez D., Liu F.F., Goodman P., Sherar M. : Radiotherapy with or without hyperthermia in the treatment of superficial localized breast cancer: Results from five randomized controlled trials. International Collaborative Hyperthermia Group. Int J Radiat Oncol Biol Phys, 35 : 731-744, 1996.

4) Hua Y., Ma S., Fu Z., Hu Q., Wang L., Piao Y. : Intracavity hyperthermia in nasopharyngeal cancer: A phase III clinical study. Int J Hyperthermia, 27 : 180-186, 2011.

5) Jones E.L., Oleson J.R., Prosnitz L.R., Samulski T.V., Vujaskovic Z., Yu D., Sanders L.L., Dewhirst M.W.: Randomized trial of hyperthermia and radiation for superficial tumors. J Clin Oncol, 23 : 3079-3085, 2005.

6) Overgaard J., Gonzalez Gonzalez D., Hulshof M.C., Arcangeli G., Dahl O., Mella O., Bentzen S.M. : Randomised trial of hyperthermia as adjuvant to radiotherapy for recurrent or metastatic malignant melanoma. European Society for Hyperthermic Oncology. Lancet, 345 : 540-543, 1995.

7) Valdagni R., Amichetti M. : Report of long-term follow-up in a randomized trial comparing radiation therapy and radiation therapy plus hyperthermia to metastatic lymph nodes in stage IV head and neck patients. Int $\mathbf{J}$ Radiat Oncol Biol Phys, 28 : 163-169, 1994.

8) Perez C.A., Gillespie B., Pajak T., Hornback N.B., Emami B., Rubin P.: Quality assurance problems in clinical hyperthermia and their impact on therapeutic outcome : A report by the Radiation Therapy Oncology Group. Int $\mathbf{J}$ Radiat Oncol Biol Phys, 16 : 551-558, 1989.

9) Perez C.A., Pajak T., Emami B., Hornback N.B., Tupchong L., Rubin P.: Randomized phase III study comparing irradiation and hyperthermia with irradiation alone in superficial measurable tumors. Final report by the Radiation Therapy Oncology Group. Am J Clin Oncol, 14 : 133-141, 1991.

10) Datta N.R., Bose A.K., Kapoor H.K., Gupta S. : Head and neck cancers : Results of thermoradiotherapy versus radiotherapy. Int J Hyperthermia, 6: 479-486, 1990.

11) Sherar M., Liu F.F., Pintilie M., Levin W., Hunt J., Hill R., Hand J., Vernon C., van Rhoon G., van der Zee J., Gonzalez D.G., van Dijk J., Whaley J., Machin D.: Relationship between thermal dose and outcome in thermoradiotherapy treatments for superficial recurrences of breast cancer: data from a phase III trial. Int $\mathbf{J}$ Radiat Oncol Biol Phys, 39 : 371-380, 1997.

12) Feldmann H.J., Seegenschmiedt M.H., Molls M. : Hyperthermia-its actual role in radiation oncology. Part III : Clinical rationale and results in deep seated tumors. Strahlenther Onkol, $171: 251-264,1995$.

13) Song C.W., Rhee J.G., Lee C.K., Levitt S.H.: Capacitive heating of phantom and human tumors with an 8 MHz radiofrequency applicator (Thermotron RF-8). Int J Radiat Oncol Biol Phys, 12 : 365-372, 1986.

14) Ohguri T., Yahara K., Moon S.D., Yamaguchi S., Imada H., Terashima H., Korogi Y. : Deep regional hyperthermia 
for the whole thoracic region using $8 \mathrm{MHz}$ radiofrequency-capacitive heating device: relationship between the radiofrequency-output power and the intra-oesophageal temperature and predictive factors for a good heating in 59 patients. Int J Hyperthermia, 27 : 20-26, 2011.

15) Emami B., Myerson R.J., Scott C., Gibbs F., Lee C., Perez C.A. : Phase I/II study, combination of radiotherapy and hyperthermia in patients with deep-seated malignant tumors: Report of a pilot study by the Radiation Therapy Oncology Group. Int J Radiat Oncol Biol Phys, 20 : 73-79, 1991.

16) Hiraoka M., Nishimura Y., Nagata Y., Mitsumori M., Okuno Y., Li P.Y., Abe M., Takahashi M., Masunaga S., Akuta K. : Site-specific phase I, II trials of hyperthermia at Kyoto University. Int J Hyperthermia, 10: 403-410, 1994.

17) Myerson R.J., Scott C.B., Emami B., Sapozink M.D., Samulski T.V. : A phase I/II study to evaluate radiation therapy and hyperthermia for deep-seated tumours: A report of RTOG 89-08. Int J Hyperthermia, 12: 449-459, 1996.

18) Anscher M.S., Samulski T.V., Leopold K.A., Oleson J.R. : Phase I/II study of external radio frequency phased array hyperthermia and external beam radiotherapy in the treatment of prostate cancer: Technique and results of intraprostatic temperature measurements. Int J Radiat Oncol Biol Phys, 24 : 489-495, 1992.

19) van der Zee J., Gonzalez Gonzalez D., van Rhoon G.C., van Dijk J.D., van Putten W.L., Hart A.A. : Comparison of radiotherapy alone with radiotherapy plus hyperthermia in locally advanced pelvic tumours: A prospective, randomised, multicentre trial. Dutch Deep Hyperthermia Group. Lancet, 355: 1119-1125, 2000.

20) Mitsumori M., Zeng Z.F., Oliynychenko P., Park J.H., Choi I.B., Tatsuzaki H., Tanaka Y., Hiraoka M. : Regional hyperthermia combined with radiotherapy for locally advanced non-small cell lung cancers: A multi-institutional prospective randomized trial of the International Atomic Energy Agency. Int J Clin Oncol, 12: 192-198, 2007.

21) De Haas-Kock D.F., Buijsen J., Pijls-Johannesma M., Lutgens L., Lammering G., van Mastrigt G.A., De Ruysscher D.K., Lambin P., van der Zee J. : Concomitant hyperthermia and radiation therapy for treating locally advanced rectal cancer. Cochrane Database Syst Rev: CD006269, 2009.

22) Lutgens L., van der Zee J., Pijls-Johannesma M., De Haas-Kock D.F., Buijsen J., Mastrigt G.A., Lammering G., De Ruysscher D.K., Lambin P. : Combined use of hyperthermia and radiation therapy for treating locally advanced cervix carcinoma. Cochrane Database Syst Rev: CD006377, 2010.

23) Berdov B.A., Menteshashvili G.Z. : Thermoradiotherapy of patients with locally advanced carcinoma of the rectum. Int J Hyperthermia, 6: 881-890, 1990.

24) Harima Y., Nagata K., Harima K., Ostapenko V.V., Tanaka Y., Sawada S. : A randomized clinical trial of radiation therapy versus thermoradiotherapy in stage IIIB cervical carcinoma. Int J Hyperthermia, 17: 97-105, 2001.

25) Ohguri T., Imada H., Yahara K., Morioka T., Nakano K., Terashima H., Korogi Y.: Radiotherapy with 8-MHz radiofrequency-capacitive regional hyperthermia for stage III non-small-cell lung cancer: The radiofrequency-output power correlates with the intraesophageal temperature and clinical outcomes. Int J Radiat Oncol Biol Phys, 73 : 128-135, 2009.

26) Rau B., Wust P., Tilly W., Gellermann J., Harder C., Riess H., Budach V., Felix R., Schlag P.M.: Preoperative radiochemotherapy in locally advanced or recurrent rectal cancer: Regional radiofrequency hyperthermia correlates with clinical parameters. Int J Radiat Oncol Biol Phys, 48 : 381-391, 2000.

27) Issels R.D., Prenninger S.W., Nagele A., Boehm E., Sauer H., Jauch K.W., Denecke H., Berger H., Peter K., Wilmanns W. : Ifosfamide plus etoposide combined with regional hyperthermia in patients with locally advanced sarcomas: a phase II study. J Clin Oncol, 8: 1818-1829, 1990.

28) Issels R.D., Abdel-Rahman S., Wendtner C., Falk M.H., Kurze V., Sauer H., Aydemir U., Hiddemann W.: Neoadjuvant chemotherapy combined with regional hyperthermia (RHT) for locally advanced primary or recurrent high-risk adult soft-tissue sarcomas (STS) of adults: Long-term results of a phase II study. Eur J Cancer, 37 : 1599-1608, 2001.

29) Wendtner C., Abdel-Rahman S., Baumert J., Falk M.H., Krych M., Santl M., Hiddemann W., Issels R.D. : Treatment of primary, recurrent or inadequately resected high-risk soft-tissue sarcomas (STS) of adults : Results of a phase II pilot study (RHT-95) of neoadjuvant chemotherapy combined with regional hyperthermia. Eur J Cancer, 37: 1609-1616, 
2001.

30) Issels R.D., Lindner L.H., Verweij J., Wust P., Reichardt P., Schem B.C., Abdel-Rahman S., Daugaard S., Salat C., Wendtner C.M., Vujaskovic Z., Wessalowski R., Jauch K.W., Durr H.R., Ploner F., Baur-Melnyk A., Mansmann U., Hiddemann W., Blay J.Y., Hohenberger P.: Neo-adjuvant chemotherapy alone or with regional hyperthermia for localised high-risk soft-tissue sarcoma: A randomised phase 3 multicentre study. Lancet Oncol, 11: 561-570, 2010.

31) Kondo M., Itani K., Yoshikawa T., Tanaka Y., Watanabe N., Hiraoka M., Noguchi M., Miura K. : [A prospective randomized clinical trial comparing intra-arterial chemotherapy alone and when combined with hyperthermia for metastatic liver cancer]. Gan To Kagaku Ryoho, 22 : 1807-1811, 1995. (Japanese)

32) Ishikawa T., Kokura S., Sakamoto N., Ando T., Imamoto E., Hattori T., Oyamada H., Yoshinami N., Sakamoto M., Kitagawa K., Okumura Y., Yoshida N., Kamada K., Katada K., Uchiyama K., Handa O., Takagi T., Yasuda H., Sakagami J., Konishi H., Yagi N., Naito Y., Yoshikawa T.: Phase II trial of combined regional hyperthermia and gemcitabine for locally advanced or metastatic pancreatic cancer. Int J Hyperthermia, 28 : 597-604, 2012.

33) Shen H., Li X.D., Wu C.P., Yin Y.M., Wang R.S., Shu Y.Q. : The regimen of gemcitabine and cisplatin combined with radio frequency hyperthermia for advanced non-small cell lung cancer: A phase II study. Int J Hyperthermia, 27 : 27-32, 2011.

34) Schlemmer M., Wendtner C.M., Lindner L., Abdel-Rahman S., Hiddemann W., Issels R.D. : Thermochemotherapy in patients with extremity high-risk soft tissue sarcomas (HR-STS). Int J Hyperthermia, 26 : 127-135, 2010.

35) Fotopoulou C., Cho C.H., Kraetschell R., Gellermann J., Wust P., Lichtenegger W., Sehouli J. : Regional abdominal hyperthermia combined with systemic chemotherapy for the treatment of patients with ovarian cancer relapse : Results of a pilot study. Int J Hyperthermia, 26 : 118-126, 2010.

36) Cho C., Wust P., Hildebrandt B., Issels R.D., Sehouli J., Kerner T., Deja M., Budach V., Gellermann J.: Regional hyperthermia of the abdomen in conjunction with chemotherapy for peritoneal carcinomatosis: Evaluation of two annular-phased-array applicators. Int J Hyperthermia, 24 : 399-408, 2008.

37) Jiang Z., Yan W., Ming J., Yu Y.: Docetaxel weekly regimen in conjunction with RF hyperthermia for pretreated locally advanced non-small cell lung cancer: A preliminary study. BMC Cancer, 7 : 189, 2007.

38) Maluta S., Dall’Oglio S., Romano M., Marciai N., Pioli F., Giri M.G., Benecchi P.L., Comunale L., Porcaro A.B. : Conformal radiotherapy plus local hyperthermia in patients affected by locally advanced high risk prostate cancer: Preliminary results of a prospective phase II study. Int J Hyperthermia, 23 : 451-456, 2007.

39) Kitamura K., Kuwano H., Watanabe M., Nozoe T., Yasuda M., Sumiyoshi K., Saku M., Sugimachi K.: Prospective randomized study of hyperthermia combined with chemoradiotherapy for esophageal carcinoma. J Surg Oncol, 60 : 55-58, 1995.

40) Westermann A.M., Jones E.L., Schem B.C., van der Steen-Banasik E.M., Koper P., Mella O., Uitterhoeve A.L., de Wit R., van der Velden J., Burger C., van der Wilt C.L., Dahl O., Prosnitz L.R., van der Zee J. : First results of triple-modality treatment combining radiotherapy, chemotherapy, and hyperthermia for the treatment of patients with stage IIB, III, and IVA cervical carcinoma. Cancer, 104 : 763-770, 2005.

41) Jones E.L., Samulski T.V., Dewhirst M.W., Alvarez-Secord A., Berchuck A., Clarke-Pearson D., Havrilesky L.J., Soper J., Prosnitz L.R. : A pilot Phase II trial of concurrent radiotherapy, chemotherapy, and hyperthermia for locally advanced cervical carcinoma. Cancer, 98 : 277-282, 2003.

42) Rau B., Wust P., Hohenberger P., Loffel J., Hunerbein M., Below C., Gellermann J., Speidel A., Vogl T., Riess H., Felix R., Schlag P.M.: Preoperative hyperthermia combined with radiochemotherapy in locally advanced rectal cancer: A phase II clinical trial. Ann Surg, $227:$ 380-389, 1998.

43) Hulshof M.C., Van Haaren P.M., Van Lanschot J.J., Richel D.J., Fockens P., Oldenborg S., Geijsen E.D., Van Berge Henegouwen M.I., Crezee J. : Preoperative chemoradiation combined with regional hyperthermia for patients with resectable esophageal cancer. Int J Hyperthermia, 25 : 79-85, 2009. 